\title{
Algorithm for workcells design
}

\author{
Livia Dana Beju ${ }^{1, *}$ \\ 1"Lucian Blaga" University of Sibiu, Engineering Faculty, 550024 Sibiu, Romania
}

\begin{abstract}
The paper presents a methodology for the design of the manufacturing cells, covering all the necessary steps, from the analysis of the customers' needs, to part families for group technologies, process engineering, control procedures, production rate, production planning (push or pull workflow), supply in the manufacturing cell, workcell configuration, work standardisation. The necessary tools through each stage are presented. Also, there are presented links to major company systems. For each design stage, deliverables are specified. this design approach is not linear. At each stage it is possible (and indicated) to go back and analyse the previously established parameters. The methodology is a complex one, and in a wider space the detailed parameters will be presented in extenso.
\end{abstract}

\section{Introduction}

A workcell is a manufacturing system built in order to obtain high quality products, in a productive way, at the lowest possible cost. The equipment involved in the manufacturing process are placed next to each other, to minimize the transport of both work-pieces, products and people. Workcells simplify the flow of materials, management and even accounting systems.

The concept of organizing manufacturing cells was developed by the Toyota Manufacturing System. It still represents the basis for organizing Lean Manufacturing systems, but also the most modern ones, such as Digital Factory and Smart Manufacturing.

Apparently, manufacturing workcells seem to be simple systems. Behind this apparent simplicity there are complex technical, logistical, informational and human systems. The elements of the aforementioned systems interact with each other, so that the production flow can work as continuously as possible, without wastes, able to be adjusted and improved. The aim is to keep the level of the seven losses, defined by Toyota, to a minimum. It is also intended that the size of the production batches to be small.

Designing a workcell is a complex engineering issue that must take into account several information from different departments.

Also, the design has to go through some logical steps. At each step, new parameters of the workcell are established, starting from the analysis of the information known at that time, taking into account the imposed requirements and the technical limitations. Designers must have a deep knowledge of the elements of a workcell, the interactions between them, as well

${ }^{*}$ Corresponding author: livia.beju@,ulbsibiu.ro 
as the physical and information flows that go through the manufacturing cell. Last but not least, the necessary labour force, their level of training as well as the operators needs must be taken into account. Designing a manufacturing cell is a complex effort, involving both specialists from the production department, but also from other departments: marketing, production planning, logistics, human resources, etc.

This paper aims to present a design algorithm of the manufacturing cells, which highlights both the design steps, design tools, company systems that provide information and support, and the results needed to be established at each design stage.

\section{Workcell design - state of the art}

Work cells are the basic structures of manufacturing processes, which is why it aroused the interest of specialists.

Alfieri [1] proposes the analysis of the company as a "Systems of System" (SoS). This approach is currently used in the context of complex military or government initiatives. The author raises the issue of describing an enterprise as a system consisting of subsystems corresponding to the main aspects of manufacturing systems (resources, quality management systems, production planning and control procedures, etc.) and the relationships between them. The idea is generous but remains at the stage of a philosophical approach.

Benkamoun [2] develops a systematic design process for manufacturing systems.

Cochran [3] describes a framework for the design and implementation of production systems. This framework allows setting and communicating objectives and design solutions from the highest level to the lowest level of a manufacturing enterprise. The same author [4] presents a case study of manufacturing cells design that combine new and existing machines, showing the difficulties that may arise in such situations. Just changing the arrangement of the machines in the cells could offer some benefits, but these benefits were offset by a high level of investment required. The simulations showed long-term effects. It is difficult to design a feasible manufacturing cell just by rearranging existing equipment.

Caggiano [5] presents a case study of a manufacturing cell design in a digital manufacturing system. An existing manufacturing cell for turbine blades for aircraft engines is improved by automating and robotizing the deburring station.

De Carlo [6] presents a case study about the relocation of a manufacturing cell. Three methods of analysis are used: empirical, a method that uses a diagram of the relationships between activities, and a complex method of Lean Manufacturing analysis. The most effective proved to be the last.

Duda [7] exemplified the design of a car manufacturing cell on the principle of axiomatic design. A breakdown of the design steps is used. This example demonstrates the impact that low-level design decisions can have on high-level system objectives and the need for a systematic approach in the design of the production system.

El Maraghy [8] develops aspects of assembly cell design. Different models of assembly cells organization are presented. The characteristics of the intelligent manufacturing systems as well as the Internet of Things are highlighted. These modern structures allow the connection improvement between the physical and the digital world. In such systems good decisions can be made smart, in a faster way.

Lešková [9] presents a case study of an assembly cell design. The characteristics of the assembly workstations with a modular structure, made of aluminium profiles, are underlined. Nine principles of manufacturing cell design are discussed: continuous flow; simplicity; work organization; clear presentation of the work pieces; reconfigurability; the quality of products; maintainability; easily access and ergonomics.

Various companies [10... 14] present their own perspectives resulted from the experiences gained in the design of manufacturing cells. 
Analysing the literature in the field of manufacturing cell design, it is found that there are papers that analyse the general flows of the company without providing algorithms for the design of workcells, other papers present case studies for designing workcells for different industrial flows, and there are also few of them which analyse partial aspects of the workcell design without addressing the complex flows of the company.

This paper presents the algorithm for designing a manufacturing cell, regardless of the industry in which it operates. All the elements that make up the manufacturing cell are taken into account, as well as the physical and information flows that run through it.

\section{Algorithm for manufacturing cell design}

The algorithm starts from the market requirements, on the basis of which the product families are established. A manufacturing cell will be designed for each product family. Product families, respectively related group technologies can be established by: intuitive grouping (simple parts / mixed processes), production flow analysis with the use of matrices for sorting parts (products with medium complexity / mixed processes) or by coding and classification (high complexity products / mixed processes).

The next step is process engineering. The tact time is computed, based on the requirements of the customers and our available time.

A database is created with all the information regarding the technological flow (operations, equipment, durations - operation cycle times, worker cycle times, equipment cycle times, set-up times, waiting times), presented as well structured as possible (tables). The required number of equipment, workers and process efficiency are computed. On the basis of this information, a preliminary balancing of the workers activities can be made and the preliminary size of the production batch can be established.

The methods of intermediate and final control, and the implementation of the "Total Quality Management System" are establish next.

At this point, the flow characteristics of the work pieces, passing through the manufacturing cell, must be determined. We start from the production rate, establish the number of parts in a container, the maximum number of containers needed at a time in the manufacturing cell and in the adjacent inter-operational stocks (supermarket). Now it is important to establish production type (push or pull). If the pushed flow is chosen, the required documents are set. If the pull stream is chosen, the number of cards ready to start production is determined to be placed on the Kanban board.

The next step connects the production flow with the logistics system and determines how the manufacturing cell is supplied.

Once this information is known, it is possible to proceed to the detailed design of the manufacturing cell. Many works refer only to this stage.

Finally, it is necessary to standardize the work in the manufacturing cell. The employee incentive system must also be developed and disseminated in order to achieve continuous improvement.

Table 1 shows the main steps of a workcell design.

The design process of the manufacturing cell is not linear. At each stage you can return to a previous one, in order to make corrections and improvements.

If some activities use robot or corobots, the design steps of the cell remain the same. In addition, the concrete aspects related to the parameters of robots and corobots will be analysed. 
Table 1. Algorithm for work cell design.

\begin{tabular}{|c|c|c|c|c|}
\hline & Task & Working tools & $\begin{array}{l}\text { Enterprise } \\
\text { system }\end{array}$ & What is obtained \\
\hline 1 & \multicolumn{4}{|c|}{ Part families (ordered by the customers) for group technologies } \\
\hline 1a & $\begin{array}{l}\text { Establish the estimated } \\
\text { volume of products that } \\
\text { will be ordered by the } \\
\text { customers in the next } \\
\text { period }\end{array}$ & $\begin{array}{l}\text { Analysis of the orders from previous, } \\
\text { analogous periods; } \\
\text { Forecasts of the customers' demand. }\end{array}$ & $\begin{array}{l}\text { Marketing system } \\
\text { Planning system } \\
\text { Logistic system } \\
\text { IT system }\end{array}$ & $\begin{array}{l}\text { The number of products } \\
\text { (from each category) } \\
\text { required to be produced in } \\
\text { the unit of time }\end{array}$ \\
\hline $1 \mathrm{~b}$ & $\begin{array}{l}\text { Group technologies; } \\
\text { Parts with similar } \\
\text { shapes, that can be } \\
\text { produced on the same } \\
\text { machines (which have } \\
\text { similar production } \\
\text { routes) are grouped. }\end{array}$ & $\begin{array}{l}\text { Intuitive grouping; } \\
\text { Production flow analysis with the use of } \\
\text { matrices for sorting parts; } \\
\text { Coding and classification; }\end{array}$ & $\begin{array}{l}\text { Production system } \\
\text { Planning system } \\
\text { IT system }\end{array}$ & $\begin{array}{l}\text { The number of } \\
\text { manufacturing cells and the } \\
\text { range of parts that are } \\
\text { manufactured in each } \\
\text { workcell }\end{array}$ \\
\hline 2 & \multicolumn{4}{|l|}{ Process engineering } \\
\hline $2 \mathrm{a}$ & Takt time & Computing formula & $\begin{array}{l}\text { Marketing system } \\
\text { Logistic system } \\
\text { Planning system } \\
\text { Production system }\end{array}$ & Takt time $[\mathrm{s}]$ \\
\hline $2 b$ & $\begin{array}{l}\text { Analyse the } \\
\text { technological processes }\end{array}$ & $\begin{array}{l}\text { Analysis of existing technologies; } \\
\text { Measurements. }\end{array}$ & Production system & $\begin{array}{l}\text { Tables with all the } \\
\text { parameters that characterize } \\
\text { the production process }\end{array}$ \\
\hline $2 \mathrm{c}$ & $\begin{array}{l}\text { Compute of the required } \\
\text { number of equipment; }\end{array}$ & Computing formula & Production system & Necessary equipment \\
\hline
\end{tabular}




\begin{tabular}{|c|c|c|c|c|}
\hline $2 \mathrm{~d}$ & $\begin{array}{l}\text { Compute the required } \\
\text { number of workers }\end{array}$ & Computing formula & Production system & $\begin{array}{l}\text { Number of workers } \\
\text { required in a manufacturing } \\
\text { cell }\end{array}$ \\
\hline $2 \mathrm{e}$ & Process efficiency & Computing formula & Production system & $\begin{array}{l}\text { Subunit value; in the case } \\
\text { of a small value, process } \\
\text { optimizations are sought } \\
\text { and the number of workers } \\
\text { is reduced; Resume the } \\
\text { process from point } 2 b\end{array}$ \\
\hline $2 \mathrm{f}$ & $\begin{array}{l}\text { Preliminary balancing } \\
\text { of production }\end{array}$ & $\begin{array}{l}\text { Balance the operators' activity } \\
\text { (heuristic analysis) }\end{array}$ & Production system & $\begin{array}{l}\text { Standardized Work } \\
\text { Combination Table } \\
\text { (preliminary) }\end{array}$ \\
\hline $2 \mathrm{~g}$ & $\begin{array}{l}\text { Preliminary size of } \\
\text { production batches }\end{array}$ & $\begin{array}{l}\text { Heuristic determination based on } \\
\text { previous experience, volume of ordered } \\
\text { goods, size of parts, etc. }\end{array}$ & $\begin{array}{l}\text { Production system } \\
\text { Planning system } \\
\text { Logistic system } \\
\text { IT system }\end{array}$ & $\begin{array}{l}\text { The aim is to make batches } \\
\text { as small as possible (even } \\
\text { one-piece flow) }\end{array}$ \\
\hline 3 & \multicolumn{4}{|l|}{ Control procedures } \\
\hline $3 \mathrm{a}$ & $\begin{array}{l}\text { How to perform the } \\
\text { intermediate control }\end{array}$ & $\begin{array}{l}\text { Team personnel are trained in } \\
\text { manufacturing control techniques; } \\
\text { Implementation of poka yoke devices }\end{array}$ & $\begin{array}{l}\text { Production system } \\
\text { TQM system }\end{array}$ & $\begin{array}{l}\text { Elaboration and completion } \\
\text { of documents }\end{array}$ \\
\hline $3 b$ & $\begin{array}{l}\text { How to perform the } \\
\text { final control; }\end{array}$ & $\begin{array}{l}\text { Integration of capability and maturity } \\
\text { models }\end{array}$ & $\begin{array}{l}\text { Production system } \\
\text { TQM system }\end{array}$ & $\begin{array}{l}\text { Elaboration and completion } \\
\text { of documents }\end{array}$ \\
\hline 4 & \multicolumn{4}{|c|}{ Production rate, production planning (push or pull workflow) } \\
\hline $4 \mathrm{a}$ & $\begin{array}{l}\text { Estimate the production } \\
\text { rate }\end{array}$ & $\begin{array}{l}\text { Calculations, based on demand and } \\
\text { production capacity }\end{array}$ & $\begin{array}{l}\text { Production system } \\
\text { Planning system } \\
\text { Logistic system } \\
\text { IT system }\end{array}$ & Production rate \\
\hline $4 \mathrm{~b}$ & $\begin{array}{l}\text { Number of pieces in a } \\
\text { container }\end{array}$ & $\begin{array}{l}\text { Calculations based on production rate, } \\
\text { parts dimensions; } \\
\text { Heuristic }\end{array}$ & $\begin{array}{l}\text { Production system } \\
\text { Planning system } \\
\text { Logistic system } \\
\end{array}$ & $\begin{array}{l}\text { Number of pieces in a } \\
\text { container }\end{array}$ \\
\hline
\end{tabular}




\begin{tabular}{|c|c|c|c|c|}
\hline & & & IT system & \\
\hline $4 \mathrm{c}$ & $\begin{array}{l}\text { Estimate the number of } \\
\text { required containers }\end{array}$ & $\begin{array}{l}\text { Calculations } \\
\text { Heuristic }\end{array}$ & $\begin{array}{l}\text { Production system } \\
\text { Planning system } \\
\text { Logistic system }\end{array}$ & $\begin{array}{l}\text { The maximum number of } \\
\text { containers required at a } \\
\text { time in the manufacturing } \\
\text { cell and in the inter- } \\
\text { operational stocks } \\
\text { (supermarkets) }\end{array}$ \\
\hline $4 \mathrm{~d}$ & Production scheduling & $\begin{array}{l}\text { Specific methods of analysis and } \\
\text { production planning }\end{array}$ & $\begin{array}{l}\text { Production system } \\
\text { Planning system }\end{array}$ & $\begin{array}{l}\text { For the push flows } \\
\text { (documents); } \\
\text { For the pull flows (cards } \\
\text { ready to start production, } \\
\text { placed on the Kanban } \\
\text { board). }\end{array}$ \\
\hline 5 & \multicolumn{3}{|c|}{ Supply in the manufacturing cell } & \\
\hline $5 \mathrm{a}$ & $\begin{array}{l}\text { Establish how parts and } \\
\text { information move. } \\
\text { Design the withdrawal } \\
\text { Kanban and eventually } \\
\text { production Kanban }\end{array}$ & $\begin{array}{l}\text { Analysis and development of these } \\
\text { systems }\end{array}$ & $\begin{array}{l}\text { Production system } \\
\text { Planning system } \\
\text { Logistic system } \\
\text { IT system }\end{array}$ & $\begin{array}{l}\text { Number of cards; } \\
\text { Algorithms for moving } \\
\text { parts and information; } \\
\text { Card locations. }\end{array}$ \\
\hline $5 b$ & $\begin{array}{l}\text { Establish the size of the } \\
\text { supermarket stocks (in } \\
\text { front and behind the } \\
\text { manufacturing cell) }\end{array}$ & $\begin{array}{l}\text { Calculations } \\
\text { Heuristic analysis }\end{array}$ & $\begin{array}{l}\text { Production system } \\
\text { Logistic system }\end{array}$ & $\begin{array}{l}\text { Number of containers in } \\
\text { each supermarket stock for } \\
\text { each type of product; } \\
\text { The area for each } \\
\text { supermarket stock. }\end{array}$ \\
\hline 6 & \multicolumn{3}{|l|}{ Workcell configuration } & \\
\hline $6 a$ & $\begin{array}{l}\text { Determine (calculates) } \\
\text { the space occupied by } \\
\text { each workstation, inter- } \\
\text { operational storage and } \\
\text { supermarket stocks }\end{array}$ & $\begin{array}{l}\text { Draw the shadows left on the floor by } \\
\text { each machine tool (workstation), or } \\
\text { equipment, or stock } \\
\text { Try to minimise the production system } \\
\text { cell }\end{array}$ & Production system & Sketches \\
\hline
\end{tabular}




\begin{tabular}{|c|c|c|c|c|}
\hline $6 \mathrm{~b}$ & $\begin{array}{l}\text { Identify constraints or } \\
\text { affinities }\end{array}$ & $\begin{array}{l}\text { Heuristic } \\
\text { Diagrams that analyse the connections } \\
\text { between stations }\end{array}$ & Production system & $\begin{array}{l}\text { Tables, diagrams specifying } \\
\text { the level of connection } \\
\text { between workstations }\end{array}$ \\
\hline $6 c$ & $\begin{array}{l}\text { Set the cell } \\
\text { configuration }\end{array}$ & $\begin{array}{l}\text { U shape, or L type, or oval, or linear, etc. } \\
\text { Follow the preservation of the logical } \\
\text { sequence of the work phases through } \\
\text { discussion with the workers; } \\
\text { Try the simplest configuration that } \\
\text { ensures, low maintenance, easy } \\
\text { reconfiguration, minimal costs; } \\
\text { The cell must be kept in motion, with } \\
\text { minimal effort, small space }\end{array}$ & Production system & $\begin{array}{l}\text { Manufacturing cell } \\
\text { location plan }\end{array}$ \\
\hline $6 \mathrm{~d}$ & $\begin{array}{l}\text { Analyse the phases of } \\
\text { each operation and } \\
\text { handling }\end{array}$ & Timing & $\begin{array}{l}\text { Production system } \\
\text { HR system }\end{array}$ & $\begin{array}{l}\text { Documents describing the } \\
\text { phases of each operation, } \\
\text { durations }\end{array}$ \\
\hline $6 e$ & $\begin{array}{l}\text { Ergonomic analysis of } \\
\text { operators' work }\end{array}$ & $\begin{array}{l}\text { Filming } \\
\text { Timings } \\
\text { Analysis }\end{array}$ & $\begin{array}{l}\text { Production system } \\
\text { HR system }\end{array}$ & $\begin{array}{l}\text { Documents with proposals } \\
\text { for improvement }\end{array}$ \\
\hline $6 f$ & $\begin{array}{l}\text { Establishes the activity } \\
\text { for each operator; }\end{array}$ & $\begin{array}{l}\text { Techniques for balancing the operators' } \\
\text { work }\end{array}$ & Production system & $\begin{array}{l}\text { Standardized Work } \\
\text { Combination Table - } \\
\text { preliminary }\end{array}$ \\
\hline $6 g$ & Design specific devices & $\begin{array}{l}\text { Try to design modular devices that allow } \\
\text { adjustments, small changes } \\
\text { Make sure that the elements ensure } \\
\text { positioning, rotation, processing; } \\
\text { Use universal fastening systems that can } \\
\text { be used for different sizes; } \\
\text { Large components must be easily moved; } \\
\text { Minimize any movement that does not } \\
\text { add value. }\end{array}$ & $\begin{array}{l}\text { Design department } \\
\text { Supply department } \\
\text { Production system }\end{array}$ & $\begin{array}{l}\text { General drawings } \\
\text { Devices }\end{array}$ \\
\hline
\end{tabular}




\begin{tabular}{|c|c|c|c|c|}
\hline $6 \mathrm{~h}$ & $\begin{array}{l}\text { Establish locations for } \\
\text { storing tools, devices }\end{array}$ & $\begin{array}{l}\text { Design of storage areas and do } \\
\text { appropriate coding; } \\
\text { Organize easy access to tools, } \\
\text { consumables, equipment, components. }\end{array}$ & $\begin{array}{l}\text { Design department } \\
\text { Production system } \\
\text { Supply department }\end{array}$ & Tools and devices location \\
\hline $6 \mathrm{i}$ & Visual management & $\begin{array}{l}\text { Place open signals to improve } \\
\text { communication between team members } \\
\text { and for fast, real-time visual } \\
\text { management. } \\
\text { Use Andon lights and dashboards to } \\
\text { signal line status }\end{array}$ & $\begin{array}{l}\text { Production system } \\
\text { Supply department }\end{array}$ & Signalling \\
\hline 7 & \multicolumn{3}{|l|}{ Standardization } & \\
\hline $7 \mathrm{a}$ & $\begin{array}{l}\text { Make and sign } \\
\text { documents }\end{array}$ & $\begin{array}{l}\text { Establish standard working procedures; } \\
\text { Include testing, quality control, } \\
\text { inspection, packaging procedures in the } \\
\text { job description to minimize reprocessing; } \\
\text { Give workers the right to stop the line in } \\
\text { the case of non-conformities. }\end{array}$ & Production system & $\begin{array}{l}\text { Process capacity sheet; } \\
\text { Standardized Work Chart; } \\
\text { Standardized Work } \\
\text { Combination Table. }\end{array}$ \\
\hline $7 \mathrm{~b}$ & Staff motivation & $\begin{array}{l}\text { The flexible design of the cells must be } \\
\text { scalable and encourage continuous } \\
\text { change and improvement }\end{array}$ & Production system & $\begin{array}{l}\text { Employee stimulation } \\
\text { system }\end{array}$ \\
\hline
\end{tabular}




\section{Conclusions}

Although, at present, most production systems are based on manufacturing cells, the literature has not been presented a concise but complex algorithm for their design. The present paper aims to achieve this. The main stages of designing workcells are presented. These are: part families for group technologies, process engineering, control procedures, production rate, production planning (push or pull workflow), supply in the manufacturing cell, workcell configuration, work standardisation.

At each stage are specified the main systems (departments) of the company that provide information for design.

Also, the concrete products that are obtained after each stage are specified. It should be noted that this design approach is not linear. At each stage it is possible (and indicated) to go back and analyse the previously established parameters. The limited space of the paper did not allow the detailing of the tools used in each stage. This is desirable to be done in a larger space, where concrete examples can be presented.

The algorithm is also suitable for the design of robotic, agile and SMART cells. Specific adaptations can be easily made on the red thread shown.

\section{References}

1. A. M. Alfieri, M. Cantamessa, F. Montagna, IFAC Proceedings, 42, Issue 4, 1014 (2009)

2. N. Benkamouna*, W. ElMaraghyb, A.Huyeta, K. Kouissa Procedia CIRP, 17, 88 (2014)

3. D. Cochran, International Automotive Manufacturing Conference and Exposition, Detroit, Michigan May 11-13, SAE TECHNICAL PAPER SERIES (1999)

4. D. Cochran, J. Duda, J. Linck and S. Taj, Production and Operations Management Society, March, 1998

5. A. Caggiano, R. Teti, Cogent Engineering 5, (2018)

6. F. De Carlo, M.A. Arleo, O. Borgia, M. Tucci, Int. j. eng. bus. manag., 5, 35 (2013),

7. J. Duda, D. Cochran, J. Castaneda-Vega, M. Baur, R. Anger, S.Taj, International Automotive Manufacturing Conference and Exposition Detroit, Michigan, May (2019)

8. H. ElMaraghy, W. Elmaraghy, Procedia CIRP 44, 4 (2016)

9. A. Lešková, Annals Of Faculty Engineering Hunedoara - International Journal of Engineering, Tome XI, 2 (2013).

10. *** Bosch Rexroth Corporation "Lean Manufacturing Principles, Tools and Methods", https://www13.boschrexroth-us.com/Catalogs/Lean_Manufactuting_Guidebook.pdf

11. *** https://ottomotors.com/blog/workcell-design-lean-manufacturing

12. *** WORK CELL DESIGN

13. https://www.webpages.uidaho.edu/mindworks/Lean/Lecture $\% 20$ Notes/ME $\% 20410 \% 2$ 0Lecture $\% 20$ Slides $\% 2007 \% 20$ Cell\%20Design.pdf

14. *** http://m.strategosinc.com/celldesign.htm

15. *** https://blog.robotiq.com/the-right-way-to-design-a-cobot-cell-layout 